\title{
The relationship between corporate turnover and degree of diversification in South African listed industrial companies
}

\author{
Rob Mackintosh \\ Graduate School of Business, University of Cape Town
}

\begin{abstract}
The view is widely held in the literature on business policy that not only does structure follow strategy, but that size (measured in terms of turnover) and diversification strategy are closely correlated. This paper examines the relationship between degree of diversification and sales turnover of several South African listed companies which undertook diversification strategies between 1970 and 1976. The results show that there is no significant correlation between turnover and degree of diversification among these companies. Both small and large firms are seen to have similar degrees of diversification. The findings suggest that firms should avoid diversifying into several different markets while having a relatively small market share in each, as both managerial and financial resources then become too thinly spread. Such companies are likely takeover candidates in recessionary periods.
\end{abstract}

S. Afr. J. Bus. Mgmt. 1982, 13: $118-120$

Daar is ' $n$ algemene siening in die literatuur oor bestuursbeleid ('business policy'), naamlik dat struktuur nie slegs op strategie volg nie, maar dat grootte (gemeet in terme van omset) en diversifiseringstrategie sterk korreleer. Hierdie artikel ondersoek die verhouding tussen graad van diversifisering en verkoopomset van verskeie Suid-Afrikaanse gelyste maatskappye wat tussen 1970 en 1976 diversifiseringstrategiee beoefen het. Die resultate dui aan dat daar geen betekenisvolle korrelasie tussen omset en graad van diversifisering in hierdie maatskappye was nie. Klein sowel as goot maatskappye toon volgens die navorsing soortgelyke vlakke van diversifisering. Die bevindings dui aan dat maatskappye diversifisering in verskeie markte behoort te vermy as hulle slegs 'n klein markaandeel in elk sou hé, omdat bestuurs- sowel as finansièle hulpbronne dan te yl versprei word. Sulke maatskappye is waarskynlike kandidate vir oornames in tye van regressie.

S.-Afr. Tydskr. Bedryfsl. 1982, 13: $118-120$

\section{Rob Mackintost}

Graduate School of Business, University of Cape Town, Rondebosch 7700, Republic of South Africa

Received April 1982; accepted June 1982

\section{Introduction}

Theories of organizational growth and development indicate that as companies grow in size, increased diversification can be expected. ${ }^{1,2,3,4}$ Wrigley, ${ }^{2,}$ p.6 has identified four major product-market strategies which are adopted by companies as they move through successive stages of organizational development (see Table 1): Single business, Dominant business, Related business, Unrelated business. Growth brings about pressures for diversification, and this is measured using a 'related ratio' (Wrigley's term), which shows the proportion of the firm's revenues derived from the largest group of business activities that are related in some way to one another. The lower the ratio, the more diversified the business.

In this paper I propose to investigate the relationship between turnover and the degree of diversification of South African listed companies.

\section{The research hypothesis}

Following on from the research discussed briefly above, the hypothesis on which this research is based is as follows: We would expect to find that

there is a significant correlation between size and diversification strategy; that is, larger companies tend to be more diversified than smaller companies.

\section{Research approach and sample selection}

At the end of 1970 (the base year for this research) there were 478 industrial companies listed on the Johannesburg Stock Exchange. Of these, 278 companies kept to their same strategic product-market categories between 1970 and $1976 .{ }^{4}$ (The period $1970-76$ was chosen to investigate those companies specifically excluded from Andrews' research because they had changed their strategic posture at some stage during the seven year period.) The 200 remaining industrial companies therefore represented companies which had changed their strategic productmarket posture in some way over the $1970-76$ period.

From this list of companies it was necessary to determine which of these 200 companies were still listed in December 1976. This provided the list of companies which - were continuously listed between $1970-76$, and

- had also changed their product-market strategy in some way in the period 1970-76.

The companies in this list were examined to determine the extent of their diversification using the related ratio 
Table 1 Summary of strategic categories

\begin{tabular}{|c|c|c|c|c|}
\hline & Single businesses & Dominant business & Related business & Unrelated business \\
\hline $\begin{array}{l}\text { Specialization ratio } \\
\text { The proportion of a firm's reve- } \\
\text { nues attributable to its largest } \\
\text { discrete product-market activity }\end{array}$ & $\begin{array}{l}\text { Largely in a single } \\
\text { business. Has a ratio } \\
\text { of } 0,95 \text { or more }\end{array}$ & $\begin{array}{l}\text { Firms that have diver- } \\
\text { sified to a small extent. } \\
\text { Has a ratio of between } \\
0,7 \text { and } 0,95\end{array}$ & $\begin{array}{l}\text { Diversified firms which } \\
\text { have a ratio of less } \\
\text { than } 0,7\end{array}$ & $\begin{array}{l}\text { Ratio considerably } \\
\text { below } 0,7\end{array}$ \\
\hline $\begin{array}{l}\text { Related ratio } \\
\text { The proportion of the firm's } \\
\text { revenues derived from the largest } \\
\text { group of business activities that } \\
\text { are related in some way to one } \\
\text { another }\end{array}$ & & & $\begin{array}{l}\text { Has a related ratio } \\
\text { of } 0,7\end{array}$ & $\begin{array}{l}\text { Has a related ratio of } \\
0,7 \text { or less }\end{array}$ \\
\hline $\begin{array}{l}\text { Vertical ratio } \\
\text { The proportion of the firm's } \\
\text { revenues attributable to all of } \\
\text { the by-products, intermediate } \\
\text { products and final products of a } \\
\text { vertically integrated sequence of } \\
\text { manufacturing operations }\end{array}$ & $\begin{array}{l}\text { Has a ratio of } 0,7 \text { or } \\
\text { more }\end{array}$ & $\begin{array}{l}\text { Has a ratio of } 0,7 \text { or } \\
\text { more }\end{array}$ & & \\
\hline
\end{tabular}

Andrews, G.S. Strategy and financial performance of South African industrial companies, 1970-1976. Unpubl. Ph.D. thesis, Graduate School of Business, University of Cape Town, pp.312-316.

as measured against their turnovers.

It should be noted that:

- Of 478 industrial companies listed in 1970, 278 maintained their strategic product-market categories between $1970-76$.

- Of the remaining $200,125(63 \%)$ were delisted between 1970 and 1976. Of these,

$113(57 \%)$ were delisted following successful takeover bids.

$12(6 \%)$ were voluntarily delisted.

- Therefore, out of 478 industrial companies in 1970 , only $75(16 \%)$ made any significant changes to their product-market strategies over the following seven years.

\section{Correlation between related ratio and turnover}

While some South African companies do publish turnover data for major product lines, most published information relates to the percentage of pre-tax profit attributable to each major division. This unavoidably served to reduce the sample of company data available for empirical testing from 75 to $56(75 \%)$.

In the statistical analysis of the data, sales turnover figures were correlated against related ratios, and a scatter diagram was produced (Figure 1). The sources of data were:

The JSE Companies lists for December 1970 and December 1976; the Stock Exchange Handbook (1970 - 1977); the JSE Monthly Bulletin (December 1979); and G S Andrews' list of companies included in Appendix II of his PhD thesis. ${ }^{4}$

\section{Defining the related ratio}

The classification of companies developed by Rumelt was adopted to assess these changes in product-market strategy. The criteria adopted by Rumelt are listed in Table 1 . The related ratio is the proportion of a firm's revenues derived from the largest group of business activities that are related in some way to one another.

Single and Dominant business categories have related ratios of more than 0,7 , while the Related business and Unrelated business categories have related ratios of 0,7 or less.

Although this ratio was developed in the context of the United States economy, research into South African listed companies $^{5}$ indicates that the 0,7 cut-off for the ratio is equally applicable to local listed companies.

\section{The research findings}

- The correlation co-efficient (R) is $-0,29$ and the significance level is 0,0148 . There is therefore no significant correlation between sales turnover and related ratios for those companies attempting diversification strategies in the period between 1970-76. We can conclude from this that over most of the last decade, diversification strategies in South Africa have not followed sales growth in any consistent way (for example, low sales $=$ single business or high sales $=$ diversified business).

For example, some companies with sales of less than R5M, and pre-tax profits of less the R1M, had related ratios as low as 0,4 , while others with sales in excess of R1600M and profits in excess of R90M (for example, Barlows, SA Breweries) exhibited the same diversification strategy (refer to Figure 1).

- Nevertheless, some clustering is in evidence for companies at the top with sales in excess of R100M (and profits in excess of $\mathrm{R} 10 \mathrm{M}$. These have related ratios of 0,5 or less (Figure 1).

The hypothesis is therefore rejected. Both small and large firms have adopted similar diversification strategies.

\section{Conclusions}

For the smaller companies, often active in several markets with low market share in each, performance tends to be poor and management expertise thinly spread. A takeover by a much larger company is often the only way to introduce new expertise, open up markets and provide access to both capital and more sophisticated financial control. (Significantly, the largest number of takeovers among 
RELATED RATIO

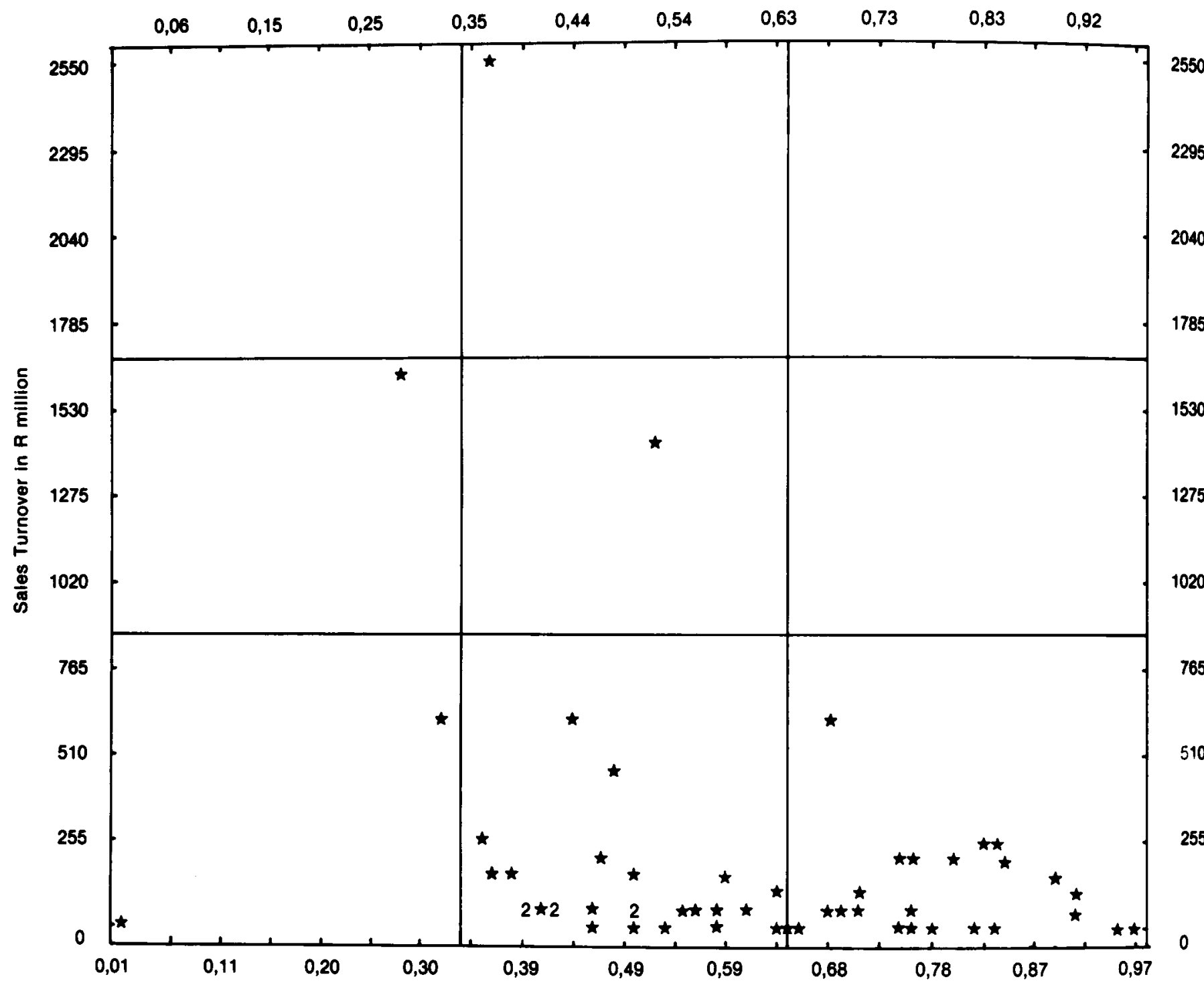

Figure 1 Scatter diagram of correlation between sales turnover and related ratios.

the 125 companies delisted occurred toward the middle of the recession in 1973.) It seems that many of these companies have attempted to diversify with few 'core skills' into too many new markets.

Small companies, active in several markets, and with low turnover in each, tend to be poor performers and probably prime takeover targets in recession periods.

It is also interesting to consider that a large proportion of South African listed companies were delisted following successful takeover bids. The possible implications are that these companiese will have no incentive to diversify from their strategic product-market positions, as they probably represent a diversification by the takeover companies themselves.

\section{References}

1. Scott, B.R. Stages of Corporate Development. ICH 9: $371-294$ Case Clearing House, Harvard Business Scool, Boston, Mass, 1971.

2. Wrigley, L. Divisional Autonomy and Diversification. D.B.A. dissertation, Harvard Business School, Boston, Mass, 1970.

3. Rumelt, R.P. Strategy, Structure and Economic Performance. Boston, Mass: Harvard University Press, 1974.

4. Andrews, G.S. Strategy and financial performance of South African listed industrial companies, Unpubl. Ph.D. Thesis, Graduate School of Business, University of Cape Town, pp.295-341.

5. Bisotto, F.E. 'South African conglomerates: A profile'. Unpubl. Technical Report, Graduate School of Business, University of Cape Town, 1980. 